\title{
FAKTOR-FAKTOR YANG BERPENGARUH TERHADAP KONSUMSI PANGAN SUMBER KARBOHIDRAT DI PERDESAAN DAN PERKOTAAN
}

\author{
(Influencing factors of Carbohydrate Food Sources Consumption in Rural and Urban Area)
}

\author{
Suci Apriani ${ }^{1}$ dan Yayuk F. Baliwati ${ }^{*}$
}

${ }^{1}$ Departemen Gizi Masyarakat, Fakultas Ekologi Manusia, Institut Pertanian Bogor, Bogor 16680

* Alamat korespondensi: Departemen Gizi Masyarakat, Fakultas Ekologi Manusia, Institut Pertanian Bogor, Bogor 16680. Telp: 0251-8621258; Fax: 0251-8622276; Email: yayuk_gm@yahoo.com

\begin{abstract}
ABST RACT
The aims of study were to analyze the ecological factors such as food availability, land capacity, population density, poverty, GDP, education; and their association to the consumption of carbohydrate food sources in some rural and urban areas of Indonesia. This ecological study was conducted by analysing the 62 districts in Indonesia. The data of food consumption was part of set Riset Kesehatan Dasar (Riskesdas 2007). The data of food production, population density, poverty, GDP, and education collected from the Central Statistic Agency (BPS). The statistical test was pearson correlation and stepwise linear regression. The study shows that consumption of carbohydrate food sources in rural more than in urban area and dominated by rice. Energy contribution from carbohydrate food sources is a half of total energy contribution (55.9\% in rural and $48.05 \%$ in urban). In rural area, consumption of rice, corn, cassava, and sweet potato per capita per year were $109 \mathrm{~kg}, 4.69 \mathrm{~kg}$, $2.51 \mathrm{~kg}$, and $0.66 \mathrm{~kg}$. While in urban area, consumption of rice, corn, cassava, and sweet potato per capita per year were $95 \mathrm{~kg}, 1.24 \mathrm{~kg}, 3.51 \mathrm{~kg}$, and $0.209 \mathrm{~kg}$. The food availability was significantly affected to the consumption of carbohydrate food sources in rural and urban areas.
\end{abstract}

Key words: carbohydrate food sources, ecological factors, rural and urban area

\section{PENDAHULUAN}

Pangan adalah salah satu kebutuhan dasar manusia yang merupakan bagian dari Hak Asasi Manusia (HAM) yang dituangkan dalam Universal Declaration of Human Rights tahun 1948 dan Undang-undang Republik Indonesia Nomor 7 tahun 1996 tentang pangan. Di dalam undang-undang tersebut juga dijelaskan pengertian ketahanan pangan, yaitu kondisi terpenuhinya pangan bagi setiap rumah tangga yang tercermin dari terpenuhinya pangan baik secara jumlah maupun mutu, aman, merata dan terjangkau.

Menurut Suryana (2004), pemenuhan kebutuhan pangan baik dari segi jumlah, mutu, gizi dan keamanannya merupakan pilar bagi pembentukan sumberdaya manusia berkualitas untuk meningkatkan daya saing bangsa Indonesia di tataran global. DKP (2006) lebih lanjut menyatakan bahwa salah satu indikator ketahanan pangan adalah terjaminnya konsumsi pangan, sesuai dengan kaidah gizi dan kesehatan serta preferensinya. Berdasarkan hasil Riskesdas 2010, disebutkan bahwa 40.6 persen penduduk Indonesia belum dapat memenuhi kebutuhan energi minimal $1<70 \%$ kecukupan AKE $2000 \mathrm{kkal} / \mathrm{kap} / \mathrm{hr}$ ). Hal tersebut menunjukkan adanya resiko terjadinya rawan pangan di Indonesia.

Berdasarkan Pola Pangan Harapan (PPH), kecukupan energi yang diperoleh dari pangan sumber karbohidrat adalah 50 persen untuk kelompok serealia dan 6 persen untuk kelompok umbi-umbian. Hal tersebut menunjukkan posisi penting pangan sumber karbohidrat dalam kecukupan energi penduduk. Selain itu, berdasarkan Susenas 2005, 43.61 persen kecukupan protein penduduk Indonesia berasal dari beras. Karena itu, ketidakcukupan pangan sumber karbohidrat bisa menjadi peringatan kewaspadaan pangan paling dini.

Jelliffe dan Jelliffe (1989) menyatakan bahwa jumlah dari variasi makanan dan zat gizi yang dikonsumsi setiap orang berbeda menurut kelompok umur serta akan bergantung pada berbagai variable ekologi seperti iklim, tipe tanah, pengelolaan pertanian, cara penyimpanan pangan, transportasi dan perdagangan pangan. Selain itu, berkaitan pula dengan perbedaan kondisi politik dan budaya, termasuk tingkat ekonomi, kebijakan pemerintah, tingkat pendidikan, jumlah dan perubahan 
penduduk karena urbanisasi maupun arus pengungsian.

Jika konsumsi pangan tidak tercukupi, khususnya pangan karbohidrat yang merupakan sumber energi maka akan rentan terjadi rawan pangan yang pada akhirnya dapat menurunkan kualitas hidup manusia. Oleh karena itu, perlu dianalisis faktor ekologi baik fisik maupun sosial ekonomi yang berpengaruh terhadap konsumsi pangan di berbagai karakteristik wilayah (perdesaan dan perkotaan) dengan pendekatan variabel ekologi berdasarkan Jelliffe dan Jelliffe (1989) sehingga permasalahan yang ada dapat diatasi secara tepat.

\section{METODE}

\section{Desain dan Lokasi}

Penelitian ini dilakukan dengan desain studi ekologi dengan memanfaatkan data sekunder dari Riskesdas 2007 maupun BPS 2007. Lokasi penelitian yaitu kabupaten yang dipilih secara purposive dengan persyaratan ketersediaan data berupa: 1) konsumsi pangan, 2) PDRB per kapita, 3) tingkat kemiskinan, 4) tingkat pendidikan penduduk usia 15 tahun ke atas, dan 5) mewakili karakteristik perdesaan dan perkotaan menurut BPS (2000). Semua data tersebut terdapat dalam kurun waktu 2007. Penelitian dilakukan selama enam bulan, yaitu bulan Oktober 2010 sampai Maret 2011.

\section{Cara Pemilihan Sampel}

Unit penelitian ini adalah kabupaten di Indonesia yang dipilih dengan pemenuhan kriteria seperti tersebut di atas. Dari 347 kabupaten, terdapat 96 kabupaten yang memenuhi kriteria pertama sampai kriteria keempat. Kemudian dilakukan pengklasifikasian unit penelitian berdasarkan karakteristik wilayah perdesaan dan perkotaan menggunakan klasifikasi BPS 2000 (BPS 2007). Untuk menentukan suatu daerah termasuk perdesaan dan perkotaan digunakan suatu indikator komposit (indikator gabungan) yang skor atau nilainya didasarkan pada skor atau nilai dari tiga buah variabel yaitu kepadatan penduduk, persentase rumah tangga pertanian, dan akses fasilitas umum.

Hasilnya didapatkan 31 kabupaten dengan karakteristik perkotaan dan 65 kabupaten dengan karakteristik perdesaan. Unit penelitian atau contoh untuk wilayah perdesaan hanya diambil 31 kabupaten karena akan dilakukan uji beda dengan wilayah perkotaan. Pengambilan contoh pada wilayah perdesaan dilakukan berdasarkan proporsi tiap wilayah (kepulauan).

\section{J enis dan Cara Pengumpulan Data}

Data sekunder yang digunakan meliputi data konsumsi penduduk yang merupakan data Riset Kesehatan Dasar (RISKESDAS 2007). Data konsumsi yang digunakan adalah data konsumsi pangan sumber karbohidrat (beras, jagung, ubi kayu dan ubi jalar) baik dalam bentuk asli maupun olahannya.

Data karakteristik fisik wilayah dan karakteristik sosial ekonomi yang digunakan didapatkan dari publikasi BPS 2007. Data karakteristik fisik wilayah meliputi: (1) penggunaan lahan, (2) ketersediaan pangan, (3) produksi pangan sumber karbohidrat dan luas panennya, serta (4) kepadatan penduduk. Data karakteristik sosial ekonomi meliputi: (1) tingkat pendidikan penduduk usia 15 tahun ke atas, (2) PDRB per kapita, (3) tingkat kemiskinan, (4) mata pencaharian penduduk serta (5) akses fasilitas umum seperti jumlah sekolah, rumah sakit dan tempat pelayanan kesehatan lainnya, pasar, pertokoan, serta persentase pemilikian listrik dan telepon; dan (6) jumlah penduduk.

\section{Pengolahan dan Analisis Data}

Data karakteristik sosial ekonomi meliputi tingkat pendidikan, tingkat kemiskinan, dan PDRB perkapita ditabulasi dan dianalisis secara deskriptif. Untuk data konsumsi pangan sumber karbohidrat yang diketahui melalui raw data Riskesdas 2007 sudah dalam bentuk energi (kkal) sehingga tinggal dihitung jumlah konsumsi rata-rata penduduk tiap komoditas pangannya. Data konsumsi tiap komoditas dan kelompok pangan selanjutnya dibuat persentase tingkat konsumsi dengan membandingkannya berdasarkan kecukupan 2000 kkal/ kap/ hari serta kebutuhan ideal menurut kelompok pangan (50\% AKE untuk serealia dan 6\% AKE untuk umbi-umbian).

Dari data produksi pangan sumber karbohidrat dapat dihitung ketersediaan pangannya dengan menggunakan software Neraca Bahan Makanan dengan asumsi tidak ada ekspor dan impor. Selanjutnya dihitung persentase ketersediaan tiap komoditas dan kelompok pangan sumber karbohidrat berdasarkan kecukupan 2200 kkal/ kap/ hari serta membandingkan dengan kebutuhan ideal menurut 
kelompok pangan ( $50 \%$ AKE untuk serealia dan $6 \%$ AKE untuk umbi-umbian).

Data karakteristik fisik wilayah digunakan untuk menghitung daya dukung lahan untuk menyediakan pangan di wilayah tersebut. Rumus yang digunakan adalah rumus daya dukung lahan murni (Tola et al. 2007) dengan rumus:

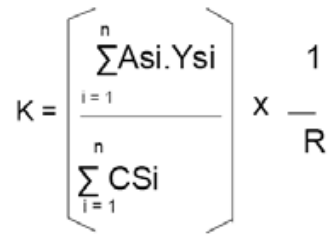

Dimana:

$\mathrm{K}$ : daya dukung lahan (orang/ha) untuk menyediakan pangan

Asi : luas lahan yang ditanami dengan jenis tanaman Si (ha)

Ysi : produksi bersih tanaman pangan $\mathrm{Si}$ (kkal/tahun)

Csi : tingkat konsumsi untuk masing - masing jenis tanaman pangan dalam menu penduduk ( $\% \mathrm{kal} /$ tahun)

$\mathrm{R}$ : kebutuhan energi rata-rata per orang (kkal/ orang/ tahun)

Analisis inferensia yang digunakan adaIah uj i beda Independent Sample T-test, korelasi pearson, dan analisis regresi linier berganda dengan metode stepwise. Uji beda Independent Sample T-test digunakan untuk menganalisis perbedaan setiap variabel yang diteliti di wilayah perdesaan dan perkotaan. Uji korelasi pearson digunakan untuk menganalisis hubungan variabel bebas (ketersediaan, kepadatan penduduk, daya dukung lahan, tingkat kemiskinan, PDRB perkapita dan tingkat pendidikan) dengan variabel tak bebas (konsumsi pangan sumber karbohidrat). Besarnya pengaruh variabel bebas terhadap variabel tidak bebas diuji dengan menggunakan uji analisis regresi linear berganda metode stepwise.

\section{HASIL DAN PEMBAHASAN}

Kawasan perkotaan sebagian besar (83.9\%) terdapat di pulau Jawa, sedangkan kawasan perdesaan tersebar di pulau-pulau besar Indonesia kecuali Maluku dan Papua yang tidak termasuk menjadi contoh penelitian. Hal tersebut menunjukkan bahwa distribusi pembangunan belum merata penyebarannya, sehingga masih terpusat di pulau Jawa.

\section{Konsumsi Pangan Sumber Karbohidrat di Perdesaan dan Perkotaan}

Konsumsi pangan sumber karbohidrat didominasi oleh beras baik di perdesaan maupun perkotaan. Jumlah konsumsi pangan sumber karbohidrat di perdesaan lebih tinggi di perdesaan daripada di perkotaan (Tabel 1). Konsumsi pangan sumber karbohidrat di perdesaan mencapai $1118 \mathrm{kkal} / \mathrm{kap} / \mathrm{hari}$ dan di perkotaan hanya $961 \mathrm{kkal} / \mathrm{kap} / \mathrm{hari}$. Tingginya konsumsi pangan sumber karbohidrat di perdesaan menurut Bouis (1990); Hussain (1990) diacu dalam Braun et al. (1993) dapat diasumsikan karena pekerjaan masyarakat perdesaan cenderung membutuhkan banyak energi dibandingkan pekerjaan masyarakat perkotaan. Oleh karena itu, kebutuhan energi masyarakat perdesaan cenderung lebih besar dan makanan masyarakat perdesaan seringkali lebih banyak didominasi pangan pokok (sumber energi yang yang relatif murah) dibandingkan makanan masyarakat perkotaan.

Berdasarkan uji beda independent sample t-test (Tabel 1) terdapat perbedaan yang nyata antara konsumsi kelompok serealia dan umbi-umbian serta jenis pangan beras dan ubi jalar di perdesaan dan perkotaan.

Tabel 1. Jumlah dan Tingkat Konsumsi Pangan Sumber Karbohidrat menurut Kebutuhan Energi Ideal (\%) di Perdesaan dan Perkotaan

\begin{tabular}{|c|c|c|c|c|c|}
\hline \multirow[b]{2}{*}{ Variabel } & & \multicolumn{4}{|c|}{ J enis Pangan } \\
\hline & & Beras & \multirow{2}{*}{$\begin{array}{r}\text { J agung } \\
4.69\end{array}$} & \multirow{2}{*}{$\begin{array}{c}\begin{array}{c}\text { Ubi } \\
\text { Kayu }\end{array} \\
2.51\end{array}$} & \multirow{2}{*}{$\begin{array}{c}\begin{array}{c}\text { Ubi } \\
\text { Jalar }\end{array} \\
0.66\end{array}$} \\
\hline - Konsumsi & $\mathrm{D}$ & 109 & & & \\
\hline (kg/ kap/th) & $\mathrm{K}$ & 95 & 1.24 & 3.51 & 0.209 \\
\hline -Konsumsi & D & 1087 & 17 & 11 & 3 \\
\hline (kkal/ kap/th) & $\mathrm{K}$ & 941 & 4 & 15 & 1 \\
\hline \multirow{2}{*}{ •\%AKE ideal } & D & 108.7 & 1.7 & 9.2 & 2.5 \\
\hline & $\mathrm{K}$ & 94.1 & 0.4 & 12.5 & 0.83 \\
\hline \multirow{2}{*}{\multicolumn{2}{|c|}{$\begin{array}{l}\text { - } \text { P jenis pangan } \\
\text { - p kelompok } \\
\text { pangan }\end{array}$}} & $0.010^{* *}$ & 0.07 & 0.244 & 0.029 ** \\
\hline & & \multicolumn{2}{|c|}{$0.000 * *$} & \multicolumn{2}{|c|}{$0.032^{* *}$} \\
\hline
\end{tabular}

* Kebutuhan konsumsi energi ideal berdasarkan kelompok pangan: beras dan jagung $=50 \%$ AKE $(1000$ kkal/ kap/hr), ubi kayu dan ubi jalar=6\% AKE (120 kkal/ kap/hr)

** Signifikan pada $\mathrm{p}<0.05$

$\mathrm{D}=$ Desa $\mathrm{K}=$ Kota

Konsumsi jagung dan ubi jalar di perdesaan lebih tinggi daripada di perkotaan. Rendahnya tingkat konsumsi jagung di perkotaan menurut Mauludyani (2008) adalah karena kurang beragamnya ketersediaan produk olahan jagung untuk dikonsumsi. Sementara itu, ubi jalar merupakan jenis pangan sumber karbohidrat yang paling sedikit dikonsumsi. Rendahnya konsumsi ubi jalar karena pengolahan ubi 
jalar belum terlalu dikembangkan sehingga produk olahannya terbatas. Perbandingan yang terbalik terjadi pada konsumsi ubi kayu yang lebih tinggi di perkotaan dibandingkan dengan di perdesaan. Cukup tingginya konsumsi ubi kayu karena semakin beragamnya produk olahan ubi kayu yang dikembangkan, khususnya di wilayah perkotaan.

Konsumsi pangan secara kualitatif ditentukan berdasarkan komposisi keragaman pangannya dalam memenuhi kebutuhan energi atau yang dikenal dengan istilah Pola Pangan Harapan (PPH). Berdasarkan PPH, konsumsi kelompok serealia secara ideal adalah 50 persen AKE (DKP 2006). Konsumsi kelompok serealia di perdesaan telah melampaui lebih dari 50 persen AKE berdasakan standar PPH. Namun di perkotaan, konsumsi kelompok serealia belum mencapai 50 persen AKE berdasarkan standar PPH. Hal tersebut diduga karena masyarakat perkotaan mengkonsumsi pangan lebih beraneka ragam. Konsumsi umbiumbian secara ideal adalah 6 persen AKE dan data konsumsi aktual masih jauh dari angka ideal tersebut. Konsumsi kelompok umbiumbian bahkan belum mencapai 1 persen baik di perdesaan maupun perkotaan, padahal di Indonesia tersedia berbagai jenis umbi-umbian dengan harga yang relatif murah (Tabel 2 ).

Tabel 2. Tingkat Kecukupan Konsumsi menurut Kelompok Pangan (\%) Dibandingkan dengan Standar PPH di Perdesaan dan Perkotaan

\begin{tabular}{crr}
\hline J enis Pangan & \multicolumn{2}{c}{ Wilayah } \\
& Perdesaan & Perkotaan \\
\hline Tingkat Kecukupan: & & \\
Serealia & 55.2 & 47.3 \\
Umbi-umbian & 0.7 & 0.8 \\
Standar PPH : & & \\
Serealia & 50.0 & 50.0 \\
Umbi-umbian & 6.0 & 6.0 \\
\hline
\end{tabular}

Ariani (2004) menyatakan bahwa di Indonesia beras telah dijadikan komoditas politik dan strategis, sehingga kebijakan pangan yang ditetapkan oleh pemerintah bias pada beras, termasuk diantaranya kebijakan 'raskin'. Kebijakan yang bias pada beras ini berdampak pada pergeseran pola konsumsi pangan pokok, dari jagung atau umbi-umbian ke beras. Selain itu, Martianto dan Ariani (2004) diacu dalam Mauludyani (2008) menyatakan terdapat beberapa alasan yang mendasari dipilinnya beras sebagai pangan pokok, yaitu cita rasa yang lebih enak, lebih cepat dan praktis diolah, dan mempunyai komposisi gizi yang relatif lebih baik dibandingkan pangan pokok yang lain.
Selain itu, beras diidentikkan dengan pangan pokok yang memiliki status sosial tinggi.

\section{Karakteristik Fisik Wilayah di Perdesaan dan Perkotaan}

Ketersediaan Pangan

Ketersediaan pangan di wilayah perdesaan lebih besar (2185 kkal) dibandingkan dengan perkotaan (1934 kkal) meskipun dengan selisih yang tidak terlalu berbeda. Hal tersebut dibuktikan dengan hasil uj $\mathrm{i}$ beda independent sample t-test (Tabel 3) yang menunjukkan bahwa meskipun jumlah ketersediaan di perdesaan lebih tinggi namun tidak berbeda nyata $(p>0.05)$.

Tabel 3. Jumlah dan Tingkat Ketersediaan Pangan Sumber Karbohidrat menurut Kebutuhan Energi Ideal di Pedesaan dan Perkotaan*

\begin{tabular}{|c|c|c|c|c|c|}
\hline \multirow[b]{2}{*}{ Variabel } & & \multicolumn{4}{|c|}{ Jenis Pangan } \\
\hline & & Beras & J agung & $\begin{array}{c}\text { Ubi } \\
\text { Kayu }\end{array}$ & $\begin{array}{l}\text { Ubi } \\
\text { Jalar }\end{array}$ \\
\hline \multirow{4}{*}{$\begin{array}{l}\text { - Ketersediaan } \\
\text { (kg/ kap/th) } \\
\text { - Ketersediaan } \\
\text { (Kal/ kap/th) }\end{array}$} & $\mathrm{D}$ & 177.76 & 33.07 & 58.39 & 14.30 \\
\hline & $\mathrm{K}$ & 167 & 4 & 45.89 & 7.73 \\
\hline & D & 1768 & 117 & 246 & 54 \\
\hline & K & 1671 & 40 & 194 & 29 \\
\hline \multirow{2}{*}{$\bullet \%$ AKE ideal } & D & 160.7 & 10.6 & 186.7 & 41.2 \\
\hline & $\mathrm{K}$ & 151.9 & 3.6 & 146.7 & 22.3 \\
\hline \multirow{2}{*}{\multicolumn{2}{|c|}{$\begin{array}{l}\text { - P jenis pangan } \\
\text { - p kelompok } \\
\text { pangan }\end{array}$}} & 0.531 & 0.079 & 0.336 & 0.131 \\
\hline & & \multicolumn{2}{|c|}{0.432} & \multicolumn{2}{|c|}{0.196} \\
\hline
\end{tabular}

* Ketersediaan energi ideal berdasarkan kelompok pangan: beras $\&$ jagung $=50 \%$ AKE $(1100 \mathrm{kkal} / \mathrm{kap} / \mathrm{hr})$ ubi kayu \& ubi jalar $=6 \%$ AKE (132 kkal/ kap/ hr) ** Signifikan pada $\mathrm{p} \ll 0,05$

$\mathrm{D}=$ Desa $\mathrm{K}=\mathrm{Kota}$

Ketersediaan pangan menurut kelompok pangan selain menunjukkan kecukupan jumlah juga dapat menunjukkan mutunya. Pada Tabel 4 ditunjukkan kontribusi setiap komoditas pangan terhadap kebutuhan ketersediaan energi ideal menurut kelompok pangan. Ketersediaan beras dan ubi kayu memiliki kontribusi yang besar terhadap pemenuhan ketersediaan sesuai kebutuhan energi ideal berdasarkan kelompok pangan. Jagung dan ubi jalar meskipun jumlahnya tidak sampai 100 persen AKE ideal namun memiliki kontribusi yang berarti.

Ketersediaan kelompok serealia baik di perdesaan dan perkotaan telah melampaui lebih dari 50 persen AKE (standar mutu keragaman berdasarkan PPH). Begitu pula dengan ketersediaan umbi-umbian yang idealnya adalah 6 persen AKE telah terpenuhi baik di perdesaan maupun perkotaan. Hal tersebut menunjukkan bahwa ketersediaan pangan sumber karbohidrat telah mencukupi secara kuantitas (jumlah) maupun kualitas (mutu) untuk 
dimanfaatkan oleh masyarakat perdesaan maupun perkotaan. Oleh karena itu, Iahan pertanian yang ada harus dimanfaatkan dengan baik untuk pemenuhan pangan masyarakat yang berkelanjutan.

Tabel 4. Tingkat Kecukupan Ketersediaan menurut Kelompok Pangan (\%) Dibandingkan dengan Standar PPH di Perdesaan dan Perkotaan

\begin{tabular}{lrr}
\hline Jenis & \multicolumn{2}{c}{ Wilayah } \\
Pangan & Perdesaan & Perkotaan \\
\hline Tingkat Kecukupan : & & \\
Serealia & 85.67 & 77.76 \\
Umbi-umbian & 13.67 & 10.14 \\
Standar PPH & & \\
Serealia & 50.0 & 50.0 \\
Umbi-umbian & 6.0 & 6.0 \\
\hline
\end{tabular}

Kepadatan Penduduk

Kepadatan penduduk merupakan rasio penduduk yang menempati suatu wilayah. BPS (2007) mengklasifikasikan kepadatan penduduk di Indonesia menjadi empat kategori; kepadatan penduduk sangat tinggi (>1000 jiwa/ $\mathrm{km}^{2}$ ), kepadatan penduduk tinggi (501-1000 jiwa/ $\mathrm{km}^{2}$ ), kepadatan penduduk sedang (101500 jiwa $/ \mathrm{km}^{2}$ ), dan kepadatan penduduk jarang $\left(<101\right.$ jiwa $/ \mathrm{km}^{2}$ ). Dari hasil uji beda independent sample t-test kepadatan penduduk di perdesaan dan perkotaan berbeda nyata $(p<0.01)$, yaitu lebih tinggi di perkotaan dibandingkan perdesaan. Rata-rata kepadatan penduduk di perdesaan adalah 249 jiwa/ $\mathrm{km}^{2}$ yang digolongkan ke dalam kepadatan penduduk sedang menurut BPS (2007) (Tabel 5). Sementara itu, rata-rata kepadatan penduduk di perkotaan adalah 1144 jiwa/ km² atau tergolong kepadatan penduduk sangat tinggi.

Tabel 5. Karakteristik Fisik Wilayah di Perdesaan dan Perkotaan

\begin{tabular}{clrrc}
\hline No & Karakteristik fisik & Desa & Kota & p \\
\hline 1 & $\begin{array}{l}\text { Kepadatan Penduduk } \\
\text { (jiwa/ } / \mathrm{km}^{2} \text { ) }\end{array}$ & 249 & 1144 & $0.000^{*}$ \\
2 & $\begin{array}{l}\text { Kepadatan Penduduk } \\
\text { (orang/ha) }\end{array}$ & 2.49 & 11.44 & $0.000^{*}$ \\
3 & $\begin{array}{l}\text { Daya Dukung Lahan } \\
\text { (orang/ha) }\end{array}$ & 6.62 & 7.16 & 0.891 \\
\hline
\end{tabular}

* Berbeda nyata pada $p<0.05$

\section{Daya Dukung Lahan}

Bertambahnya jumlah penduduk menyebabkan luas lahan garapan cenderung makin kecil, keadaan ini menyebabkan meningkatnya tekanan penduduk terhadap Iahan. Kemudian di daerah ladang berpindah kenaikan kepadatan penduduk juga meningkatkan tekanan penduduk terhadap lahan karena naiknya kebutuh- an akan pangan, akibatnya diperpendeknya masa istirahat lahan (Soemarwoto 2001 diacu dalam Tola et al. 2007). Selanjutnya, Siwi (2002) diacu dalam Tola et al. (2007) menyatakan bahwa meningkatnya kepadatan penduduk, daya dukung lahan pada akhirnya akan terlampaui. Hal ini menunjukkan bahwa lahan di suatu wilayah tidak mampu lagi mendukung jumlah penduduk di atas pada tingkat kesejahteraan tertentu (Mustari et al. 2005 diacu dalam Tola et al. 2007).

Daya dukung lahan di perdesaan adalah 6.62 orang/ ha sedangkan di perkotaan adalah 7.16 orang/ ha. Meskipun daya dukung lahan di perkotaan lebih tinggi dibandingkan dengan di perdesaan, namun daya dukung lahan tersebut telah dilampaui oleh kepadatan penduduknya yaitu 11.44 orang/ ha (Tabel 5). Menurut Mustari et al. (2005) diacu dalam Tola et al. (2007) hal tersebut menunjukkan bahwa Iahan di wilayah tersebut tidak mampu lagi mendukung jumlah penduduk di atas pada tingkat kesejahteraan tertentu.

\section{Karakteristik Sosial Ekonomi di Perdesaan dan Perkotaan}

Tingkat Kemiskinan

Tingkat kemiskinan di perdesaan dan perkotaan memiliki perbedaan nyata berdasarkan uji beda independent sample t-test $(p<0.05)$. Tingkat kemiskinan di perdesaan lebih tinggi daripada di perkotaan yaitu 21 persen dan di perkotaan yaitu 17 persen (Tabel 6). Masalah kemiskinan akan berdampak pada kurangnya akses masyarakat terhadap pemenuhan kebutuhan pangan maupun pelayanan kesehatan. Jumlah orang miskin mencerminkan kelompok yang tidak mempunyai akses pangan, jika persentasenya lebih dari 20 persen, maka akses pangannya termasuk kategori rendah. Kemiskinan adalah indikator ketidakmampuan untuk mendapatkan cukup pangan, karena rendahnya kemampuan daya beli atau hal ini mencerminkan ketidakmampuan memenuhi kebutuhan dasar seperti makan, pakaian, perumahan, pendidikan, dan lain-lain (BKP 2008).

\section{PDRB/ kapita}

PDRB/kapita di perkotaan lebih tinggi daripada di perdesaan. Di perkotaan PDRB/ kapita adalah Rp 10913000 dan di perdesaan adalah Rp 7373000 sementara itu rata-rata PDRB/ kapita di Indonesia menurut data BPS tahun 2007 adalah Rp 12721 000. Sehingga dapat dikatakan bahwa rata-rata kabupaten di Indonesia baik di perkotaan maupun perdesaan memiliki PDRB di bawah rata-rata. Hal terse- 
but sejalan dengan penelitian Ulfani (2010) yang menyatakan bahwa 72.1 persen kabupaten/kota di Indonesia memiliki PDRB/kapita yang rendah yaitu kurang dari Rp 12128150.

Perbedaan nilai PDRB/kapita di tiap wilayah dikarenakan adanya perbedaan sumberdaya alam dan pemanfaatannya dalam mendukung kegiatan perekonomian di wilayah tersebut. Menurut Zaris (1987); Yunarko (2007) diacu dalam Ulfani (2010) sumberdaya alam merupakan salah satu faktor pendukung pertumbuhan daerah, selain pola investasi dan perkembangan prasarana transportasi. PDRB/ kapita wilayah dapat menggambarkan pendapatan rata-rata penduduk di wilayah tersebut, sehingga dapat dikatakan bahwa pendapatan merupakan salah satu akses pangan yang dilihat dari aspek ekonomi.

Tabel 6. Karakteristik Sosial Ekonomi di Perdesaan dan Perkotaan

\begin{tabular}{clrrr}
\hline No & $\begin{array}{c}\text { Karakteristik sosial } \\
\text { ekonomi }\end{array}$ & D & K & p \\
\hline 1 & Tingkat Kemiskinan (\%) & 21 & 17 & $0.018^{*}$ \\
2 & $\begin{array}{l}\text { PDRB/ kapita (dalam } \\
\text { ribuan Rp) }\end{array}$ & 7373 & 10913 & 0.056 \\
3 & Tingkat Pendidikan (\%) & 72 & 64 & $0.002^{*}$ \\
\hline$*$ Berbeda nyata pada p<0.05 & & &
\end{tabular}

Tingkat Pendidikan

Tingkat pendidikan di perdesaan lebih rendah dibandingkan di perkotaan yaitu 72 persen penduduk di perdesaan hanya menamatkan pendidikan sampai sekolah dasar atau bahkan tidak menamatkannnya. Sementara itu, di perkotaan sebanyak 64 persen penduduk yang tidak sekolah atau setinggi-tingginya hanya sampai menamatkan sekolah dasar. Berdasarkan uji beda independent sample t-test, tingkat pendidikan di perdesaan dan perkotaan berbeda yang nyata $(p<0.05)$.

Menurut Syarief et al. (1988) diacu dalam Hardinsyah (2007) tingkat pendidikan formal umumnya mencerminkan kemampuan seseorang untuk memahami berbagai aspek pengetahuan, termasuk pengetahuan gizi. Dengan kata lain, seseorang yang memiliki pendidikan lebih tinggi seharusnya lebih baik dalam mengatur pola makannya sesuai dengan pengetahuan gizi yang dimiliki.

\section{Faktor Ekologi yang Berpengaruh terhadap Konsumsi Pangan Sumber Karbohidrat di Perdesaan dan Perkotaan}

Perdesaan

Konsumsi pangan sumber karbohidrat yang merupakan jumlah dari konsumsi beras, jagung, ubi kayu dan ubi jalar di perdesaan memiliki hubungan dengan ketersediaan, PDRB/ kapita, dan tingkat pendidikan menurut hasil uji korelasi pearson. Dengan analisis regresi linier (stepwise regression) diketahui pengaruh dari setiap faktor tersebut. Berdasarkan analisis regresi tersebut dapat diketahui bahwa faktor yang berpengaruh terhadap konsumsi pangan sumber karbohidrat di perdesaan yaitu ketersediaan. Persamaan regresi linier faktor yang mempengaruhi konsumsi pangan sumber karbohidrat di perdesaan sebagai berikut:

\section{$Y 1 *=1339-138 \times 1 *$}

Y1*: konsumsi pangan sumber karbohidrat di perdesaan (Y2)

$\mathrm{X} 1 *$ : ketersediaan pangan sumber karbohidrat di perdesaan (disesuaikan; 1/ X1)

Persamaan regresi linier di atas menunjukkan nilai konstanta sebesar 1339 menyatakan bahwa jika tidak ada kenaikan pada ketersediaan maka konsumsi pangan sumber karbohidrat di perdesaan sebesar 1339. Nilai koefisien regresi ketersediaan sebesar -138, menunjukkan setiap kenaikan satu nilai faktor tersebut, maka konsumsi pangan sumber karbohidrat akan berkurang sebesar nilai koefisien faktor pada persamaan linier tersebut.

Nilai $R$ square model linier adalah 0.2351 , berarti keragaman yang mampu dijelaskan oleh faktor-faktor dalam model tersebut sebesar 23.51 persen, sedangkan sisanya dijelaskan oleh faktor-faktor lain di luar model. Hasil analisis ini menggambarkan tentang konsumsi pangan sumber karbohidrat di perdesaan yang sifatnya umum tidak spesifik hanya dipengaruhi oleh ketersediaan.

Berdasarkan hasil regresi, dapat dilihat bahwa ketersediaan yang menggambarkan akses fisik terhadap pangan lebih berpengaruh daripada variabel lainnya, termasuk variabel sosial ekonomi. Hal tersebut dapat menunjukkan ketergantungan rumah tangga di perdesaan pada akses fisik karena kebutuhan energi masyarakat perdesaan cenderung lebih besar dan makanan masyarakat perdesaan seringkali lebih banyak didominasi pangan pokok (sumber energi yang yang relatif murah) dibandingkan makanan masyarakat perkotaan (Bouis 1990b; Hussain 1990 dalam Braun et al. 1993).

\section{Perkotaan}

Konsumsi pangan sumber karbohidrat di perkotaan sama halnya di perdesaan yaitu berhubungan dengan ketersediaan menurut hasil uji korelasi pearson. Berdasarkan analisis 
regresi dapat diketahui bahwa faktor yang berpengaruh terhadap konsumsi pangan sumber karbohidrat di perkotaan yaitu ketersediaan, dengan persamaan liniernya sebagai berikut:

\section{Y2*= 7.327 - $330 \mathrm{X1} *$}

Y2* : konsumsi pangan sumber karbohidrat di perkotaan (disesuaikan; Ln Y2)

$\mathrm{X} 1 *$ : ketersediaan pangan sumber karbohidrat di perkotaan (disesuaikan; $1 / \mathrm{X} 1$ )

Persamaan regresi linier di atas menunjukkan nilai konstanta sebesar 7.327 menyatakan bahwa jika tidak ada kenaikan pada ketersediaan maka konsumsi pangan sumber karbohidrat di perkotaan sebesar 7.327. Nilai koefisien regresi ketersediaan sebesar -330, menunjukkan setiap kenaikan satu nilai faktor tersebut, maka konsumsi pangan sumber karbohidrat di perkotaan akan berkurang sebesar nilai koefisien faktor pada persamaan linier tersebut.

Nilai $R$ square model linier adalah 0.2278 , berarti keragaman yang mampu dijelaskan oleh faktor-faktor dalam model tersebut sebesar 22.78 persen sedangkan sisanya dijelaskan oleh faktor-faktor lain di luar model. Hasil analisis ini menunjukkan tentang konsumsi pangan sumber karbohidrat di perkotaan yang sifatnya umum tidak spesifik hanya dipengaruhi oleh ketersediaan.

Hasil analisis regresi, menunjukkan bahwa ketersediaan yang menggambarkan akses fisik terhadap pangan lebih berpengaruh dari pada variabel lainnya, termasuk variabel sosial ekonomi. Hal tersebut dapat juga menunjukkan masih adanya ketergantungan rumah tangga di perkotaan terhadap akses fisik terhadap pangan. Adanya perpindahan penduduk dari perdesaan ke perkotaan (urbanisasi) semakin meningkatkan kebutuhan pangan masyarakat, karena itu perlu pengelolaan sumber daya pangan yang baik agar kebutuhan pangan terpenuhi secara berkelanjutan.

\section{KESIMPULAN}

Berdasarkan faktor ekologi secara fisik, antara lain kepadatan penduduk dan daya dukung lahan, kondisi di perkotaan tidak perbedaan yang nyata dengan perdesaan. Daya dukung di perkotaan lebih tinggi daripada di perdesaan, akan tetapi angka tersebut telah terlampaui oleh kepadatan penduduknya. Indikator sosial ekonomi di perkotaan lebih baik dari pada di perdesaan kecuali pada PDRB/ kapita.
Konsumsi pangan sumber karbohidrat di perdesaan lebih tinggi daripada di perkotaan. Rata-rata konsumsi pangan karbohidrat total di perdesaan yaitu $1118 \mathrm{kkal} / \mathrm{kap} / \mathrm{hari}$ dan di perkotaan yaitu $961 \mathrm{kkal} / \mathrm{kap} / \mathrm{hari}$. Begitu pula dengan ketersediaan pangan sumber karbohidrat total di perdesaan lebih tinggi daripada di perkotaan yaitu 2185 kkal/ kap / hari di perdesaan dan 1934 kkal/ kap/hari di per-kotaan.

Faktor ekologi yang berhubungan nyata dengan konsumsi pangan sumber karbohidrat total di perdesaan adalah ketersediaan, PDRB/ kapita dan tingkat pendidikan. Konsumsi pangan sumber karbohidrat total di perkotaan berhubungan nyata dengan ketersediaan. Adapun faktor ekologi yang berpengaruh terhadap konsumsi pangan sumber karbohidrat total di perdesaan maupun di perkotaan adalah ketersediaan pangan.

Saran penelitian adalah ketersediaan merupakan faktor ekologi secara fisik yang paling berpengaruh terhadap konsumsi pangan baik di perdesaan maupun di perkotaan. Oleh karena itu di perdesaan harus dioptimalkan pemanfaatan daya dukung lahan yang ada dan diperhatikan agar daya dukung lahan tersebut tidak terlampaui oleh kepadatan penduduknya sehingga dapat terpenuhi kebutuhan pangan yang berkelanjutan. Sementara itu di perkotaan meskipun ketersediaan masih mencukupi akan tetapi pertumbuhan penduduk yang semakin meningkat sehingga perlu diperhatikan dengan baik pemenuhan kebutuhan pangan penduduk yang semakin meningkat pula. Di perkotaan perlu pengoptimalan penyediaan pangan melalui pasokan agar kebutuhan pangan yang berkelanjutan dapat terpenuhi. Selain itu pemanfaatan potensi ekonomi juga perlu dioptimalkan untuk meningkatkan PDRB/ kapita dan dilakukan pendistribusian yang merata agar pembangunan pangan dapat dirasakan oleh semua pihak.

\section{DAFTAR PUSTAKA}

Ariani M. 2004. Analisis Perkembangan Konsumsi Pangan dan Gizi. Pusat Penelitian dan Pengembangan Sosial Ekonomi Pertanian, Bogor.

[BKP] Badan Ketahanan Pangan. 2008. Peta Akses Pangan Pedesaan. Badan Ketahanan Pangan, Departemen Pertanian, Jakarta. 
[BPS] Badan Pusat Statistik. 2007. Survei Sosial Ekonomi Nasional 2007. Badan Pusat Statistik Republik Indonesia, Jakarta.

Braun JV et al. 1993. Urban Food Insecurity and Malnutrition in Developing Countries, Trends, Policies, and Research Implications. International Food Policy Research Institute, Washington DC.

[DKP-Deptan] Dewan Ketahanan PanganDepartemen Pertanian. 2006. Penyusunan Neraca Bahan Makanan Indonesia. Dewan Ketahanan Pangan, Departemen Pertanian, J akarta.

Fitria. 2003. Perbandingan Pengukuran Ketahanan Pangan Rumah Tangga Miskin dengan Metode Kuantitatif dan Kualitatif di Daerah Perkotaan. Skripsi Sarjana Departemen Gizi Masyarakat dan Sumberdaya Keluarga, Fakultas Pertanian, IPB, Bogor.

Hardinsyah. 2007. Review faktor determinan keragaman konsumsi pangan. Jurnal Gizi dan Pangan, 2(2), 55-74.
Jelliffe PB \& Jelliffe EFP. 1989. Community Nutritional Assessment. Oxford University Press, New York.

Mauludyani ARP. 2008. Elastisitas Permintaan Pangan Strategis Berdasar Analisis Data SUSENAS 2005 dan Implikasinya Terhadap Konsumsi dan Upaya Perbaikan Konsumsi Pangan Masyarakat Indonesia. Skripsi Sarjana Departemen Gizi Masyarakat dan Sumberdaya Keluarga, Fakultas Pertanian, IPB, Bogor.

Suryana A. 2004. Ketahanan Pangan di Indonesia. Dalam Ketahanan Pangan dan Gizi di Era Otonomi Daerah dan Globalisasi. WNPG (hal. 39-51). LIPI, J akarta.

Tola T, Balla PT, Ibrahim B. 2007. Analisis daya dukung dan produktivitas lahan tanaman pangan di Kecamatan Batang Kabupaten J eneponto Sulawesi Selatan. J urnal IImu Tanah dan Lingkungan, 7 (1), 13-22.

Ulfani D H. 2010. Faktor-Faktor Sosial Ekonomi dan Kesehatan Masyarakat Yang Berkaitan dengan Masalah Gizi Underweight, Stunted, dan Wasted di Indonesia. Skripsi Sarjana Departemen Gizi Masyarakat, Fakultas Ekologi Manusia, IPB, Bogor. 